\title{
The Donut Dolly: A “Girl-Next-Door's" Experience in Vietnam
}

\author{
Ellysa Cassier
}

The Vietnam War polarized the public and substantially disrupted public life during the 1960s and 1970s. Although the involvement of the United States in Vietnam was the source of considerable controversy, a number of women decided to volunteer through the American Red Cross for service in Vietnam in efforts to aid and support American soldiers sent to fight there. This thesis examines the Donut Dollies' experiences both in Vietnam and at home after their return. Specifically this thesis relates their grossly inadequate training to the psychological and physical trauma they experienced in Vietnam as well as maladjustment upon returning to the United States.

Using both primary and secondary sources, I examine the relationship between their experiences of violence in Vietnam and problems of adjustment to life in America to the inadequate training provided by the American Red Cross. My research relies almost completely on interviews that I conducted with former Donut Dollies. First-hand accounts offer a perspective that is unaltered by the constructions of other historians, and thus offer a medium in which to properly compare the aforementioned aspects.

The interviews reveal a strong correlation between the inadequacy of their training and the impact of various forms of violence they experienced in Vietnam. My research also shows that these women were, or became, in some aspects of their lives, social "rebels" for the 1960s time period. This finding allows connections to be drawn between their motivations in joining the Red Cross and their actions once they returned to the United States.

Honors Thesis 016:092. Instructor: Jeffrey Cox. Supervisor: Stephen Vlastos. The University of Iowa, Spring 2014. 
What the Hell

Is a Theater of War

It certainly isn't

A nice air-conditioned building

With comfortable seats

That cushion one's body

Nor is it a place

One can leave

If they decide

By the second act

That it isn't quite

What they expected

It is not an

Exclusive men's club either

Though there are

A lot of men

Who want to believe

That war has a

"MEN ONLY"

Sign on the marquee

Is there ever

A final curtain

In a

Theater of War

"Theater of War"-_Penni Evans, Bebind the Heart

\section{Introduction}

Several publications focus on the Donut Dollies-women who served in the American Red Cross as Recreational Aides - in the Vietnam War, but these accounts appeared soon after the war and focused on different aspects than my research. The earlier works exposed the violent incidents the Donut Dollies encountered in Vietnam as well as the difficulties returning home. However, 
these books concentrated on the job-related activities of the "Red Cross girl" in Vietnam and seemingly neglected other aspects. My research mainly focuses on their difficulties adjusting to life back in the States as well as the violence, both war-related violence and sexual violence, the women encountered while in Vietnam. In my interviews conducted forty years after their service in Vietnam, these women seemed to remember these experiences most vividly. The psychological effects of these experiences can be traced back to the grossly inadequate training the SRAO (Supplemental Recreational Aides Overseas) volunteers received before serving the mandated one-year tour in Vietnam. My thesis also shows this connection between the inadequate training and the unfortunately disturbing experiences.

\section{Review of Literature}

Four publications address Donut Dolly participation in the Vietnam War. A Piece of My Heart and In the Combat Zone are both compilations of multiple personal accounts from Donut Dollies and other women who served in the war such as Army nurses. Keith Walker published A Piece of My Heart in 1985. His book was the first to expose the Donut Dollies' stories to the public and offered raw and emotional accounts of their time spent in Vietnam. Two years later in 1987, Kathryn Marshall further expanded the accounts of Donut Dollies and exposed the hardships these women faced in Vietnam in her book, In the Combat Zone. Both of these works offer unaltered first-hand accounts that provide a wealth of information regarding their experiences. Joan Puffer Kotcher wrote the most recent publication in 2011; Donut Dolly: An American Red Cross Girl's War in Vietnam focuses on her experiences as a Donut Dolly and offers limited information on the history of the SRAO organization. A few women that were interviewed expressed their feelings relating to this book. They explained that Kotcher had her own views and experiences, but they in no way exemplified the lives of most Donut Dollies.

The final publication that addresses the Donut Dollies is Heather Marie Stur's Beyond Combat: Women and Gender in the Vietnam War. Stur concentrates on three groups of women-Dragon Ladies, SRAO volunteers, and the Women's Army Corps or WACs. She concentrates on SRAO volunteers and race during the war, but otherwise does not offer a wide view of the Donut Dollies. Throughout the chapter on Donut Dollies, Stur attempts to construct the SRAO volunteers as completely innocent women who were supposed to remind the soldiers of home and remain chaste. It seemed that Stur tried to 
emphasize the image of "home" too much in order to make her point that American women were "good" for the soldiers and the Vietnamese women, or Dragon Ladies, were "bad." Additionally, as mentioned above, Stur emphasizes the idea of a "chaste" Donut Dolly. However, the Vietnam War occurred during the middle of the sexual revolution in the United States, which is evident in some of the oral histories I recorded. For instance, one woman chose to live with her boyfriend before getting married. A few women, however, defied this image by having relations with multiple men while in Vietnam. Furthermore, a few of the women went on multiple dates with multiple soldiers while on mandatory R\&R during their tours. One woman explained that men were not the only ones that needed to let off this sort of steam.

\section{Memory}

The majority of my paper accesses memory as a form of information and as the principal source. Memory is explicitly present in the interviews conducted with former Dollies. While this element is a beneficial source because the first-hand accounts give personal perspective on the war, a problem with reflection is also introduced. It is possible that these women have reformed their memories around accepted social constructions of the war. More specifically, the majority of the women admitted there was a struggle to adjust to life back in America after spending a year in Vietnam. Once they returned to the States, the volunteers were met with the reality that the majority of Americans did not want to hear about their experiences in Vietnam. This social construction caused the women to think of their experiences in these terms. These reformations present a challenge because some of the experiences may have been consciously or unconsciously altered; nevertheless, the main points addressed in these accounts greatly supplement my research. Additionally, these women's memories present an interesting juxtaposition to the American Red Cross (ARC) documents that identify specific jobs and activities for the Donut Dollies. In many ways my paper reflects this juxtaposition. I begin by identifying the ARC's specific requirements, but base my thesis completely on personal accounts. The utilization of memory allows for a personal view on the Vietnam War and its aftermath rather than strictly scholarly works. 


\section{Historical Background}

The SRAO program was originally started by the Red Cross in WWII and, at the special request of General McArthur, was continued in the Korean War and Vietnam War. ${ }^{1}$ The SRAO program began in Vietnam in 1966 at centers that were previously established by Donut Dollies who served in Korea. These bases included: Da Nang, Nha Trang, Bien Hoa, Di An, Cam Ranh Army, Cam Ranh Air Force, Dong Ba Thin, Phan Rang, Qui Nhon, An Khe, Lai Khe, and two other bases were planned for $\mathrm{Cu}$ Chi and Long Binh. ${ }^{2}$ These bases were located throughout Vietnam amidst the chaos of the war.

The interviews with the Donut Dollies showed that the American Red Cross employed various methods of recruitment in order to attract women to the Donut Dollies program. Kathy Ormond, for instance, was ultimately drawn to the American Red Cross in Vietnam through pamphlets available in the College Placement Office describing the Donut Dollies. ${ }^{3}$ These brochures gave the qualifications needed for a "Recreational Aide" including an age requirement, marital status, and an education requirement-a Donut Dolly must be between the ages of 21 and 24, single, and must have graduated college. ${ }^{4}$ Brochures were not the only form of advertising that the American Red Cross employed to recruit Recreational Aides. Flyers were also posted in College Placement offices. These posters provided the same basic information that was incorporated in the brochures and also included black and white pictures of women laughing while working together. ${ }^{5}$ These pictures showed women having fun while working which was meant to display the joy in working for the American Red Cross. These posters also made women feel like they were needed for something bigger than themselves by claiming they "will be part of a dynamic program to help maintain the high morale of American servicemen." 6 In these ways, the American Red Cross was effectively able to recruit what they believed to be desirable women for work in Vietnam.

1 Emily Strange, “Angry Black Grunt," 1998. http://www.emilydd.com/Writings/ writings/angry black grunt.htm

2 Sharon (Vander Ven) Cummings, "ARC SRAO (Donut Dollie) Frequently Asked Questions," Donut Dollies: Women in Vietnam. www.crescentwing.com/ donutdollies/faq.html\#1

${ }^{3}$ Kathy Ormond Interview with author, April 21, 2011. (Hereafter Ormond Interview).

${ }^{4}$ Ibid.

5 "It Seems Like Only Yesterday...," ARC Information booklet, [n.d], Folder 8, Box 1, Ormond Papers, IWA.

${ }^{6}$ Ibid. 
However, not just any woman was allowed to become an SRAO volunteer through the American Red Cross. The majority of these women were white as they were supposed to represent the "girl-next-door" back in America. ${ }^{7}$ However, once the American Red Cross began receiving complaints from commanders that some of their African-American soldiers were not participating in the programs due to lack of connectivity with SRAO volunteers of the same race, the ARC began allowing a few African-American women into the program in $1967 .{ }^{8}$ Women were also more readily accepted into the SRAO program if they had brothers at home because this would help the women think of the soldiers as brothers rather than as romantic objects. ${ }^{9}$ The process to become an SRAO volunteer was extensive and competitive because the ARC enforced strict requirements in order to ensure professionalism and competence. A total of 627 women served as SRAO volunteers with a starting pay of around $\$ 4,800$ per year, equivalent to $\$ 33,650$ today. ${ }^{10}$ Once hired by the ARC, women were given the option to work in Korea or Vietnam. Before deploying, the women volunteers were given about two weeks of training. ${ }^{11}$ Once in Vietnam, the Donut Dollies were sent to base camps throughout the region in order to create recreational programs also called 'clubmobiles,' for the soldiers. ${ }^{12}$ These programs were designed to distract the soldiers from battle and to give them a piece of home. However there was often a disconnect between Red Cross expectations and the reality of Vietnam.

Many of the women felt unprepared and some did not even know where the country of Vietnam was located. These women put their lives on the line to "smile" at soldiers throughout the war. Their safety was always in jeopardy and three women lost their lives while in Vietnam-one was murdered by a soldier, a second was killed in a Jeep accident, and a third succumbed to a rare blood disease. ${ }^{13}$ The Dollies stayed in Vietnam for the majority of the war, and

${ }^{7}$ Stur, 65.

${ }^{8}$ Ibid, 97.

${ }^{9}$ Ormond Interview.

10 Waveney Ann Moore, “At reunion in St. Petersburg, 'Donut Dollies' Red Cross workers swap Vietnam War stories," Tampa Bay Times, July 17, 2010. http://www.tampabay.com/news/humaninterest/at-reunion-in-st-petersburgdonut-dollies-red-cross-workers-swap-vietnam/1109704

11 Ormond Interview.

12 Stur, 66.

13 Sharon Vander Ven Cummings, "American Red Cross, SRAO April 1966-67," August 23, 1990. 
the program was eventually terminated in 1972 when the last Donut Dollies left Bien Hoa. ${ }^{14}$

\section{Kathy Ormond}

Kathy Ormond was born on December 25, 1945 in Norfolk, Virginia to Jacqueline F. and Waverly C. Ormond. ${ }^{15}$ She grew up in the same state, attended Granby High School and graduated from Mary Washington College in 1968 with a degree in Spanish. ${ }^{16}$ She was in Vietnam from July 1968 until October 1969. When Kathy Ormond arrived in Vietnam in July of 1968, the TET offensive had already occurred and the war between North Vietnam and South Vietnam was entering a stalemate. ${ }^{17}$ As aforementioned, Kathy Ormond was recruited through a College Placement Office. ${ }^{18}$ Before deciding on the American Red Cross, many women investigated other groups such as Vista and the Peace Corps. Kathy Ormond wanted to have an experience that was "exciting" but that also allowed her the opportunity to help others. ${ }^{19}$ After much deliberation, Ormond decided to apply for a position with the American Red Cross. She applied to be an American Red Cross Recreational Aide because she felt "any talent she had would help the troops." 20 Through the ARC, Ormond had the option of working in Korea or in Vietnam; Ormond opted to apply for a position in Vietnam. She assumed that most women applying would opt to work in Korea because of the "stillness and peace" and she preferred the action in Vietnam over the calmness of Korea. ${ }^{21}$ For Ormond, this training lasted two short weeks in Charlottesville, Virginia. ${ }^{22}$

During this two week training session, Ormond received a written copy of a speech by the Program Director of the American Red Cross explaining the

\footnotetext{
14 Valita A. Watson and Taylor Smith, "A Donut Dolly Reflects on Her Time in Vietnam," Howard University News Service, November 16, 2008.

15 "Norfolk Girl Goes Abroad in Red Cross," The Virginian-Pilot, June 2, 1968, Folder 1, Box 1, Kathy Ormond Papers, Iowa Women’s Archives, University of Iowa, Iowa City.

${ }^{16}$ Beth Hurdle, "Her Job was to Cheer the Fighting Men," Ledger-Star, November 15, 1969, Folder 1, Box 1, Ormond Papers, IWA.

${ }^{17}$ Mark Atwood Lawrence, The Vietnam War (New York, NY: Oxford University Press, 2008), p. 134.

18 Ormond Interview.

${ }^{19}$ Ibid.

20 Ibid.

${ }^{21}$ Ibid.

22 Ibid.
} 
nature of the war, the climate of Vietnam, and the kind of treatment to expect from the Vietnamese people. ${ }^{23}$ The speech began by recounting a story between an American Private and a Vietnamese soldier. Because distinguishing "friendlies"-Vietnamese citizens in support of the Americans-from enemy Vietnamese was an almost impossible task, the Private's commander told the Private to yell "'to hell with Ho Chi Minh"' in order to establish his allegiance. ${ }^{24}$ Later in the story, the commander found the soldier lying bloodied on the side of a road next to an equally bloodied Vietnamese man. The commander revived the Private and asked him what occurred. The Private replied by saying he had used the commander's method for establishing allegiance but the Vietnamese soldier had replied with "to hell with Lyndon Johnson." 25 The two had shaken hands in the middle of the road and were run over by a truck.

This account revealed the ambiguous nature of the war and concluded with "it doesn't matter your views on the war, our people are here and need our help." 26 Although this speech started with a darkly humorous account of Vietnamese and American soldiers, it included a serious message to those volunteering in the war: "people are getting killed in Vietnam and you must mentally prepare yourselves for the realities of a combat zone." ${ }^{27}$ Although the latter part of the speech did not describe the horrors of war in detail, it provided information on the country of Vietnam and instructions on how to treat the Vietnamese people. This training prepared Ormond for the programs she would have to make for the soldiers, but could only offer a warning as to what war would be like.

After the two weeks of training, Ormond was sent to Saigon, South Vietnam around July 5, 1968. ${ }^{28}$ Kathy Ormond and three other Donut Dollies were stationed at Tan Son Nhut Airfield in Saigon. ${ }^{29}$ From this airfield base, Ormond and the other Donut Dollies would be taken to five or six other small bases a day by helicopter. The small bases usually comprised of a group of tents and bunkers set up as a base for the soldiers as opposed to a large area. Large

23 "Vietnam," Government Document for ARC Workers, [n.d], Folder 6, Box 1, Ormond Papers, IWA.

${ }^{24}$ Ibid.

25 Ibid.

${ }^{26}$ Ibid.

27 Ibid.

${ }^{28}$ Ormond Interview.

29 Gary Kuhlmann, "Dispatches," Iowa Alumni Magazine (August 2001): [no page numbers], Folder 1, Box 1, Ormond Papers, IWA. 
areas had nicer bunkers, housing for the soldiers, and included a clubhouse where Donut Dollies would present their programs. Ormond was never stationed at a large area and was thankful for this because she felt she could connect better with the soldiers at the smaller bases. ${ }^{30}$ Ormond often served in the chow line, or food line, at the bases to meet and greet all the soldiers in the platoon. ${ }^{31}$ She could acquaint herself more personally with the men through this type of volunteering. Ormond never wanted to know the soldiers intimately as she felt she would become too attached. ${ }^{32}$

Besides volunteering in the food lines, Ormond and the other Donut Dollies presented their mobile programs to the soldiers. Usually the Dollies began their programs by stating their names and their hometown, and would subsequently ask the soldiers if anyone was from the same state. Usually the soldiers were delighted to meet another person from the same town or state. These simple introductions allowed the Donut Dollies to break the ice with the soldiers and make presenting the programs less stressful. ${ }^{33}$ These mobile programs were designed and conducted entirely by the Donut Dollies and included "a number of different activities like games, quizzes, puzzles, visual information, or stunts." 34 The soldiers were split into teams in order to spark competition and camaraderie. ${ }^{35}$ These programs were geared toward taking soldiers' minds off the war and allowing them to relax, and often revolved around current events, celebrities, or sports in the United States.

For twelve hours a day, from nine in the morning until nine at night, Ormond was at bases presenting the mobile programs with the other Donut Dollies. ${ }^{36}$ Most of Ormond's spare time at her home base was consumed by designing new games to add to the mobile programs. She would converse with the other Donut Dollies on topics that the soldiers would find interesting and the women would then plan a program around the topic. ${ }^{37}$ The soldiers appreciated Ormond's work and dedication, and they would often write and

\footnotetext{
30 Ormond Interview.

${ }^{31}$ Ibid.

32 Ibid.

${ }^{33}$ Ibid.

34 “It Seems Like Only Yesterday...," ARC information booklet, [n.d], Box 1, Ormond Papers, IWA.

35 Ormond Interview.

${ }^{36}$ Ann Norris, "Red Cross Girls Train Here for Work in Vietnam, Korea," The Daily Progress, June 27, 1968, Folder 1, Box 1, Ormond Papers, IWA.

37 Ormond Interview.
} 
thank her for the work and activities she helped to put together. ${ }^{38}$ Although many letters expressed appreciation for her service, one soldier went above and beyond appreciation to the point of infatuation with Ormond. Oscar Colbert of the $101^{\text {st }}$ Airborne often wrote Ormond expressing his love and affection for her, even stating he would "always care for her." 39 Even though soldiers confessed their love and desire for her, Ormond wrote to her mother stating, "After an entire day of seeing men and smiling at them, I'm really not up for seeing 'em at night." 40

In letters to Ormond, soldiers expressed their gratitude for her service and one even claimed that she was "one of the few American girls that know what it's really like [in Vietnam]." ${ }^{41}$ This gratitude was earned from the programs Ormond assisted in organizing, the Spanish books she handed out to the Puerto Rican soldiers, and from her dedication to the G.I.'s. After serving her mandated year in Vietnam, the American Red Cross asked Ormond to extend her tour to fifteen months. ${ }^{42}$ Although this extension allowed her to continue helping the soldiers, her decision also exposed her to more of the dangers of war. Ormond's letters home only once explained the brutality of the war. This occurred when she wrote to her mother explaining what happened when mortar shells hit her base at two in the morning. ${ }^{43}$ Her account of the incident was extremely short and she only explained that she and the other Donut Dollies were forced to wear heavy, bulletproof jackets and hide in the bunkers until the bombardment had stopped. ${ }^{44}$ Beyond this account, Ormond never wrote of combat events that happened during the war.

The interview with Ormond revealed that she faced much more than just shelling. During her service as a Donut Dolly, Ormond survived artillery fire, a red alert at Lai-Khe, and a helicopter crash. The severity of artillery fire depended on which base Ormond was stationed. The first base was under mortar fire only a handful of times but the second base she was stationed at

${ }^{38}$ Frank to Kathy Ormond, November 11 [1968], Folder 3, Box 1, Ormond Papers, IWA.

${ }^{39}$ Oscar Colbert to Kathy Ormond, [n.d.], Folder 13, Box 1, Ormond Papers, IWA.

${ }^{40}$ Kathy Ormond to Jacqueline F. Ormond, November 17, 1968, Folder 4, Box 1, Ormond Papers, IWA.

${ }^{41}$ Bobby to Kathy Ormond, August 12, 1969, Folder 3, Box 1, Ormond Papers, IWA.

42 Beth Hurdle, "Her Job was to Cheer the Fighting Men," November 15, 1969, Box 1, Ormond Papers, IWA.

${ }^{43}$ Kathy Ormond to Jacqueline F. Ormond, Aug. 15, 1968, Box 1, Ormond Papers, IWA.

${ }^{44}$ Ibid. 
was termed "Rocket Alley." 45 "Rocket Alley" was under fire a few times a week and sometimes twice a night. Ormond said she was quickly able to tell which mortars were incoming and which were outgoing by the sounds they made; those "outgoing would make a sound cutting through the air and then explode." 46 Ormond also survived a red alert at Lai-Khe. Ormond explained that she and the other Donut Dollies had been picked up from the helicopterlanding pad and were transported back to their base at Lai-Khe. On the way back to their base, they were informed that a red-alert for a ground attack was in effect. Upon their return, Ormond described the base as "quiet and completely still." 47 Once the Dollies reached their home base, the Captain told them to wear their fatigues and boots and stay in the bunkers all night. They were also prohibited from making any noise or moving from the bunker. Once the alert was over or the fighting was getting close to the Dollies' bunker, someone would get them and take them to a safer location. ${ }^{48}$

The red alert at Lai-Khe was not the last danger Ormond faced. While over the ocean en route to a base, the helicopter she was in began to rapidly lose altitude. The pilot spotted a beach nearby and started a quick descent, but the rough landing caused the helicopter to tilt up onto its nose and land abruptly on the beach. Ormond was unharmed during the entire event and later learned that an American mechanic who was displeased with the war had sabotaged the helicopter. He put $\mathrm{t}$-shirts between the blades of the helicopter so during the flight the t-shirts would get caught in the blades and halt its flight. ${ }^{49}$

Throughout all of these experiences, Ormond claimed that she was never afraid. She felt that fear was not an option because these situations were lifeand-death. Ormond also stated that she was angry rather than fearful when she was shot at and mortared by the Vietcong. ${ }^{50}$ Ormond also said that she was often too tired to feel fear and would not concentrate on the fear because fear could do nothing to help her. ${ }^{51}$ In October 1969, Ormond finished her fifteenmonth tour in Vietnam and was sent back to the United States. On her last days in Vietnam she would go out to the bases and keep her sunglasses on to

\footnotetext{
45 Ormond Interview.

46 Ibid.

47 Ibid.

48 Ibid.

${ }^{49}$ Ibid.

${ }^{50}$ Ibid.

${ }^{51}$ Ibid.
} 
hide her tears due to crying because she "felt like a traitor for leaving." ${ }^{2}$ Her obvious distress over leaving the soldiers showed Ormond's compassion for the G.I.'s and her desire to help them. Although Ormond's duties as a Recreational Aide for the American Red Cross affected the soldiers, they also affected her.

The adjustment back into civilian society was not easy. She continued to work as a Recreational Aide at a military hospital in Virginia for four years. ${ }^{53}$ She recalls that her work there helped her adjust back into society because the people working at the hospital had also experienced the horrors of war. Their understanding of her experiences helped her to cope with what she had seen. ${ }^{54}$ Ormond found it difficult to accomplish daily tasks and could not stay in one place for more than five minutes at a time. She could not sit still long enough to read a book even though it was an activity she had loved to do before she left for Vietnam. ${ }^{55}$ This restlessness came from the need for her constant attention and movement at the Army bases. Ormond also found that those who had not experienced Vietnam were quick to judge her participation. They often made rude remarks regarding her service and did not respect her contributions because they had become tired of hearing about the war. ${ }^{56}$ These remarks were so frequent and harsh that Ormond stopped explaining her work in Vietnam. Instead of recounting her experiences when asked about her work after college, Ormond began saying that she "worked overseas." 57

Ormond's experiences in the Vietnam War and the re-adjustment period after coming home shaped her opinions about the war. She said that serving as a Donut Dolly was the "best thing she ever did" and that every job she had after the American Red Cross "paled in comparison to Vietnam." 58 This was because she felt she did something with her life to help other people. Although Ormond enjoyed her experiences in the war, she felt that the war was "a terrible war" and that the United States "didn't need to be there." ${ }^{59}$ Even though she

52 Sue Davis Smith, "Women of the War: Time to Remember Those Who Served in Vietnam," November 7, 1993, Box 1, Ormond Papers, IWA.

53 Ormond Interview.

${ }^{54}$ Ibid.

55 Ibid.

56 Ibid.

57 Ibid.

${ }^{58}$ Ibid.

${ }^{59}$ Ibid. 
felt the war was unjust she, in reference to the soldiers, said, "They were there so I wanted to be there." 60

\section{Jeanne Christie}

Jeanne Christie was born in Madison, Wisconsin and grew up in the Midwest. ${ }^{61}$ As a child, her life was different than most.

I had polio as a child and was always left to do what I wanted to do or it wouldn't happen. For example, my parents were told if I wanted to learn to walk again they had to leave me on the floor until I figured out how to get up...Tough love technique. I was also used in many of the March of Dimes promotions and fundraising events. I was pushed about in a wheelchair batting my big blue eyes and flipping long blonde curls talking to people and getting their money. I was raised a social do-gooder from the start. ${ }^{62}$

Christie graduated from the University of Wisconsin in 1967 with a degree in Art Education. ${ }^{63}$ At the age of 21, Christie found out about the SRAO program through a woman at UW whose mother knew Christie's father. The ARC program was one of two options for Christie; the other was a teaching position in Battle Creek, Michigan. ${ }^{64}$ The SRAO program was a "way out of the 1966 women's trap" and Vietnam was a "chance for adventure."65 Christie's motivations were not war related. She explained, "I had no clue [about the war] but to help the soldiers was an acceptable way to demonstrate a willingness to help." 66 Besides this Christie explained, "I wanted to do something different before I became an old-maid school teacher." 67

Christie had an extensive interview process with the ARC. Her first interview was in Wisconsin and she was then flown to St. Louis for a corporate interview. At this corporate interview, Christie met with a doctor. According to Christie, he asked her to perform certain actions that she was not expecting,

\footnotetext{
${ }^{60}$ Ibid.

${ }^{61}$ Kathryn Marshall, In the Combat Zone: An Oral History of American Women in Vietnam (Boston: Little, Brown \& Co, 1987): 170.

62 Jeanne Christie Interview with author, September 11, 2013. (Hereafter Christie Interview).

${ }^{63}$ Ibid.

${ }^{64}$ Ibid.

65 Ibid.

${ }^{66}$ Ibid.

${ }^{67}$ Ibid.
} 
"He asked me if I could squat! And I had to do so in front of him. I always thought that very weird and hoped it was to test my flexibility." 68 After her interviews, Christie was given the choice of Vietnam or Korea. "I really wanted to go to Vietnam-Korea was cold, and after the long winters in Wisconsin I had no desire to be cold again." 69 After placement in Vietnam, Christie was given a letter of what she would need before attending training in Washington D.C. Stateside training lasted about two weeks where "protocol was taught and military ranks were drummed into our heads." 70 They were also told how to wear the uniforms and when to wear civilian clothes along with role-playing activities regarding programs. After the training Christie still felt that "we hadn't the foggiest idea of what we were doing or what we were getting ourselves into." 71

Christie was ill preparedly sent to Vietnam in January of 1967. Throughout her 13-month tour, Christie was stationed at Nha Trang, Da Nang, and Phan Rang. ${ }^{72}$ Each base was a new experience with new soldiers. Her first station was at Da Nang with the First Marine Division where she often got out in the field to program. ${ }^{73}$ Christie and the other Donut Dollies were picked up at dawn and driven to six or eight bases a day where they would put on programs for the soldiers. When out in the field the men loved everything they did and watched in total awe; "nothing we did escaped them." 74 Their programs were generally well received by the units except for one instance about which Christie remarked, "At one location we had the Officer show up in his speedo bikini and tell us we could not see his men until we 'serviced' him. We left instead and I put him on report when we got back home.”75

Apart from this instance, Christie had relative success with her programs. Christie had "a goofy one [program] based on Mad Magazine cartoons" that interested the soldiers and encouraged them to participate. ${ }^{76}$ The Donut Dollies on base were required to invent their own programs and activities: "I was nuts and had been an art major so that was enough for me. But we all

\footnotetext{
${ }^{68}$ Ibid.

${ }^{69}$ Marshall, 171.

${ }^{70}$ Christie Interview.

${ }^{71}$ Marshall, 171.

${ }^{72}$ Christie Interview.

73 Marshall, 176.

${ }^{74}$ Ibid, 176.

${ }^{75}$ Christie Interview.

${ }^{76}$ Ibid.
} 
contributed and created programs we could generally work." 77 Besides working with the healthy soldiers, the Dollies would program in the hospital. This entailed convincing the wounded that everything would be okay: "You learned to smile and cry at the same time, until you built up a façade and could literally look at somebody dying and smile like Miss America or whatever we personified to them." 78

Any free time that Christie had she spent either in the orphanage or having fun on the job. She swam, fished, went shopping, organized parties at the orphanage, and "partied hardy."79 She didn't always enjoy attending the officers' parties but "some guys were 'safe to be around' and were fun. Many were just dirty old/young men." 80

Like most who were sent to Vietnam, Christie witnessed the ugly, violent side of war. She experienced "sniper fire, beatings, personal violence, killings and fraggings, suicides, alerts and big air attacks, dried body part collections, penises in jars" and more. ${ }^{81}$ These horrors began during her time in Nha Trang. While at Nha Trang, the most miserable thing Christie saw and heard was the "thud of body bags being taken off trucks." 82 Additionally, while she was in Nha Trang, two "nurses" 83 were shot and killed by a G.I. One of the women was dating several of the men on base and one soldier did not want to sharehe went to her quarters and shot her, her roommate and then himself. ${ }^{84}$ After this incident Christie felt that the Donut Dollies were "expendable commodities." ${ }^{55}$ She also encountered a terrorist attack while in Nha Trang; a Vietnamese child attempted to blow up a restaurant they were going into. As she was exiting the cab, she heard a gunshot—a soldier had shot the kid as he ran away. This was not an uncommon event in Vietnam. ${ }^{86}$ Later on, an ARVN guard broke into Christie's quarters and stole jewelry and money off the top of her dresser. She chose not to yell or startle the guard because he was armed. Christie did not report the guard until later when she witnessed him beating

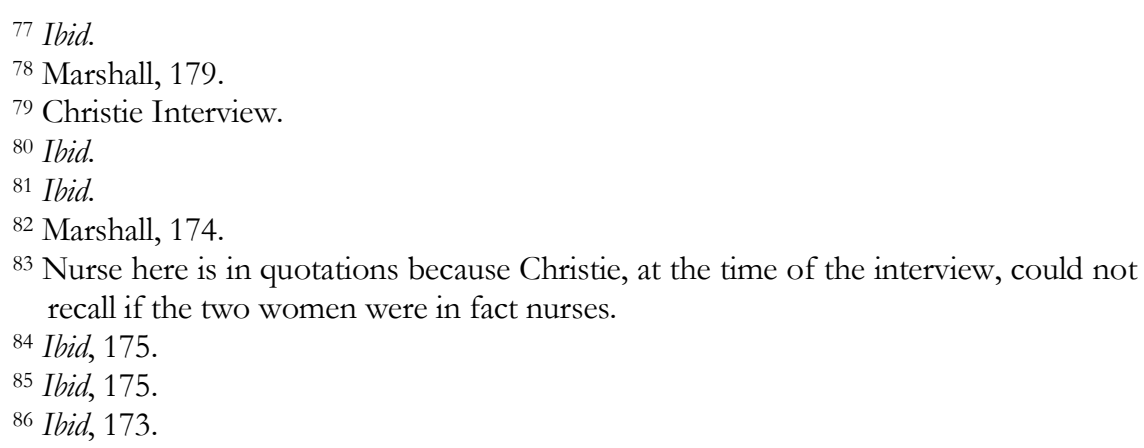


the housekeepers during the day. However the Red Cross could not replace the guard because he was the best security the hootch could get. ${ }^{87}$

The worst problem that Christie encountered was the prevalence of sexual assault. In her interview with the author, Christie explained the issue; "The problem that nobody talked about back then-having it happen to you was a fate worse than death-is being raped." This would happen when the men got very drunk or "stretched their psychological limit and just go crazy." 88 The military offered no resources for women who were assaulted. "The military was very nasty about it [rape], and naturally it was always the woman's fault. In Nam [Vietnam] I knew some of the options that were offered any gal who found herself in a family way. None of them were pleasant and none of them left the gal with an ounce of self-respect." ${ }^{99}$ Christie also had encounters with the Vietcong. "At night I would walk out in the driveway and hear something or somebody running off in the brush. It really made you wonder if you were being watched. We also had some ARC gals' photos appear in VC pocketsthey'd taken pictures and were either tracking the gals down or watching them." $" 90$

Despite the horrors of war, Christie established relationships with not only the soldiers but also the Vietnamese. Bien, Christie's housekeeper, invited her over for tea with her family. While she was there, Bien's neighbors touched Christie's hair in awe because they had never seen blonde hair before. After tea, Bien's husband would not let Christie walk home as it was a dishonor on the family. ${ }^{91}$ Christie also had other Vietnamese friends and good relationships with the people until she had to turn in a Vietnamese child in for stealing guns. Christie did not believe that the child had done such a thing, but was required to do so anyways. ${ }^{92}$

Christie returned from Vietnam right before the TET offensive. At this point, she was doing anything she could to get out of the country because she simply could not handle Nam anymore and was ready to go home. ${ }^{93}$ However when she got home, she found that America was a very different world.

\footnotetext{
${ }^{87}$ Ibid, 175.

88 Ibid, 180.

${ }^{89}$ Ibid, 181.

${ }^{90}$ Ibid, 181.

${ }^{91}$ Ibid, 173.

${ }^{92}$ Christie Interview.

${ }_{93}$ Marshall, 182.
} 
Christie got home and did not know what to do. She was "in limbo" and "life didn't function the way it had before"; all of this made her extremely angry. ${ }^{94}$ Eventually these feelings began to wear on Christie- she cried a lot and wanted to be back in Vietnam because she felt she fit in there and not in America. ${ }^{95}$ Part of this out-group feeling was due to the fact that no one believed she had been in Vietnam and could not comprehend the fact that she did not want to settle down and have a family. ${ }^{96}$ Christie got angry at women who had no clue about the war and frustrated when decisions were not made quickly. ${ }^{97}$ Society tolerated Christie but believed she was wild because she challenged the social norm. Eventually Christie learned to not talk about her experiences. ${ }^{98}$

After a short period, Christie accepted a job with the ARC at the Great Lakes Naval Hospital — she was the first woman to be stationed at the hospital after Vietnam. ${ }^{99}$ Christie then moved to Miami, Ohio and got a master's in Education Supervision. While in Miami, Christie sealed off Vietnam and her experiences, essentially letting the memories fade. She found a job in Guam upon graduation as associate director for the USO (United Service Organizations). ${ }^{100}$ While in Guam, Christie met her husband and they moved back to the States. ${ }^{101}$ Her condition quickly spiraled downward when a group of friends from Vietnam decided to look at pictures of their time in Vietnam. She went through some rough days and could not function on a normal level. One day she walked around the house for an extended period of time with a measuring cup looking for sugar for cookies. Christie felt she could not tell her experiences to her husband because "I knew people who had been to Nam were the ones who could begin to understand, but I felt that it wasn't right to burden them with my problems." 102 Christie eventually attended a vet center rap session where a bunch of Veterans got together to talk about their experiences with a friend, Peter. When she got to the center, the vets told her she could not come into the meeting because they felt women did not serve in the same way as men during Vietnam. She remarked this "totally demolished

\footnotetext{
94 Ibid, 183.

${ }^{95}$ Ibid, 183.

${ }^{96}$ Christie Interview.

${ }^{97}$ Ibid.

${ }^{98}$ Ibid.

99 Marshall, 183.

100 Ibid, 183.

${ }^{101}$ Christie Interview.

102 Marshall, 184.
} 
[me]. They had leveled me right there." 103 After deliberation, the vets remembered there were women in Vietnam and allowed her into the meeting. Christie eventually began to come out of her spiral. ${ }^{104}$ She said, in reference to her responses to her children's questions, "When my children-many years later-asked me what I did in the war, the explanation I ended up with was that some people patched others up, some people shot others, I played games."105

\section{Barbara "Bobbi" Stephens}

Barbara, or Bobbi, Stephens was born in West Virginia. She was the only girl in a family with four younger brothers, one of which also served in Vietnam. Stephens grew up "a corporation brat," which she described as similar to an army brat but with her father working for Kroger, a grocery company. ${ }^{106}$ Due to her father's occupation, the family constantly moved around the United States. Between moves, Stephens graduated from Ohio University in 1966 with a degree in Political Science and History; her specialization in History included a fascination with the "Far East," which furthered her eventual interest in the American Red Cross (ARC). ${ }^{107}$ Out of college, the NSA offered Stephens a five-year contract. Stephens, however, was reluctant to accept the job. She explained that she "had just turned twenty-one and really didn't want to commit to five years. I wanted to explore the world so I ended up working for BCBS (Blue-Cross Blue-Shield Washington." 108 After one year of work with BCBS, Stephens moved to California and became a self-professed "beach bum." She lived in an apartment on the beach in Malibu and worked with a friend by "selling designer products to architects and engineers." 109

After two years living “the golden years," Stephens' parents requested she return to Cleveland because she had become too immersed in the Californian culture. Stephens acquiesced and began searching for a job that allowed her to travel to the Far East. Thus Stephens discovered East Aid, an organization that

103 Ibid, 185.

104 Ibid, 185.

105 Ibid, 177-78.

106 Barbara Stephens Interview with author, July 31, 2013. (Hereafter Stephens Interview).

107 Ibid.

108 Ibid.

109 Ibid. 
did volunteer work in the area that Stephens wished to travel. ${ }^{110}$ At that time, the organization had frozen the hiring process and could not offer her a job until the following August. In the meantime, Stephens began volunteer work with the Kennedy Foundation. This foundation held particular interest for Stephens because it began to offer programs for which her youngest brother was eligible. ${ }^{111}$ While volunteering, Stephens met a woman who worked for the Red Cross. During coffee breaks, Stephens talked with this woman about her desire to travel to the Far East. The Red Cross volunteer told Stephens about the Supplemental Recreational Aide Overseas (SRAO) program and put her in contact with a woman in the Cleveland Red Cross chapter. ${ }^{112}$

Stephens called the Cleveland chapter and went down to meet with the woman. The chapter explained the various jobs available overseas then asked Stephens if she would be interested in conducting local television interviews with some women who had recently returned from their tours. Through these interviews, Stephens gained insight into Donut Dollies, Field Directors, and Service Voluntary Hospitals. She was able to glean information regarding "the emotional drain and the frustration of living overseas... and that didn't deter me."113 Ultimately Stephens chose the SRAO program because she was "simply a tom boy." She officially applied, was cleared, and scheduled to train in Washington D.C. in January 1969, the week of Nixon's inauguration. Those close to Stephens had mixed emotions about her decision to join the SRAO program. Her mother was a "stay-at-home adventurist" and was mildly concerned, as she had no idea what Stephens' role would be in Vietnam. Stephen's oldest brother was already enlisted in the Army because "his draft number came up [and] he had signed up for everything he could sign-up for and he was going to be graduated from helicopter flight school." 114 Thus he had no idea of her plans. A boyfriend was a "White House follower" and expressed to Stephens, "I just can't believe you are doing this. I am on the 'inside' and you don't know what you are getting yourself into." Stephens admitted to having no idea what she was getting into and was "clueless."115

Stephens arrived in Washington D.C. with her family in January and stayed two weeks for training. During training, the Red Cross did not dwell on

\section{Ibid.}

111 Stephens' youngest brother had Down Syndrome.

112 Stephens Interview.

113 Ibid.

114 Ibid.

115 Ibid. 
violence or fear but concentrated on programs. Stephens also received the Red Cross uniform, a seersucker blue dress. ${ }^{116}$ Once Stephens got to Saigon, she was issued a helmet, called a "steel pot" by the Donut Dollies, a flack vest, and combat boots. She arrived after dark, around midnight, at Tan Son Nhut airport in Saigon and was escorted onto an old school bus with the rest of the SRAO volunteers. A military Vietnam guard escorted the bus of SRAO volunteers to the downtown district of Saigon. While on the way to Saigon, the bus was stopped at various checkpoints by the military to ensure that the travelers were indeed Donut Dollies and not North Vietnamese militants.

Stephens was assigned first to Bien Hoa, a "fairly large base" because it was both an Army and an Air Force base. ${ }^{117}$ Before sent to Bien Hoa, Stephens and the other Donut Dollies in country were given careful instructions to follow all orders because they "were there at the pleasure of the military." This was the only intimidating information Stephens was given from the Red Cross. The first night in Bien Hoa, Stephens and the other six girls in the unit were invited to a barbeque at the Air Force base. This party "blew [Stephens'] mind" as "it was a unit bar, not an officer's club, or an NCO club." 118 Bien Hoa was home to the " $20^{\text {th }}$ Brigade Engineers, which built roads, did all that kind of stuff for South Vietnam." The headquarters for the $20^{\text {th }}$ Brigade was positioned across from the hootch where the Donut Dollies lived. This hootch allowed for each woman to have an individual bedroom and included a large supply and workroom to plan programs. ${ }^{119}$

After about two weeks in Vietnam, Stephens witnessed her first ground attack. While hanging laundry to dry, she heard weird noises and notified her unit director. The director told Stephens that she was supposed to have her helmet and flak jacket on and to not be outside. This instance was the first of three days of ground attacks. ${ }^{120}$ During one of these attacks, the $11^{\text {th }}$ Armored Cavalry called and asked if the Donut Dollies could come and serve Kool-Aid to the men. The director immediately nixed this idea. Stephen explained that this was one of the lighter moments while in Vietnam.

Bien Hoa did not have a Recreational Center and all of the programs were presented through mobile units. Stephens got "really into" developing

\footnotetext{
116 Ibid.

117 Ibid.

118 Ibid.

${ }^{119}$ Ibid.

${ }^{120}$ Ibid.
} 
programs because all programs had to be developed from original ideas and materials. She teamed up with another Donut Dolly; her partner would create the props for the programs and Stephens would develop the general ideas. ${ }^{121}$ The Donut Dollies created programs based on what was occurring in the United States at the time. For instance, Stephens developed a program called "The ARC 500," which was tied into cars and Memorial Day. The Donut Dollies would plan multiple activities to fill an entire hour. Stephen claimed that the "most unique thing about programming is just playing the game."

Stephens' brother, John, was set to enter Vietnam while she was stationed at Bien Hoa. Before this occurred, Stephens made an effort to know the operations officers of every helicopter unit at Bien Hoa to try and secure her brother's placement at Bien Hoa. When he came to Vietnam, Bien Hoa was under ground attack and he was thus processed through Long Binh. ${ }^{122}$ After the ground attack, Stephens called John and acquired his service number, which she promptly gave to the operations officers. Later he called Stephens back and told her he was assigned to the $20^{\text {th }}$ Brigade Engineers. This station put him literally across the street from Stephens. While this was a "Red Cross no-no," 123 everyone on base was "sworn to secrecy," which allowed Stephens to live near her brother for some time. ${ }^{124}$ This closeness allowed for an ease of communication between Stephens, John, and their family.

This secrecy lasted for a few months until the beginning of April when the Red Cross discovered the proximity of the Stephens siblings. Stephens and one of the other Donut Dollies were on a helicopter flight back to Bien Hoa when the pilot explained, "we are going down and auto-rotating." 125 Stephens had learned helicopter jargon from her brother and was reassured by this statement from the pilot. However when the helicopter did a mayday, the elephant grass was so tall that it extended above the helicopter blades. This caused a dangerous situation, as the enemy would have been incredibly difficult to detect. The pilot gave the code for downed helicopter with Donut Dollies on board-round eyes-while the gunners forced the two SRAO volunteers under the helicopter for added protection. After a few minutes, a second helicopter arrived to escort the stranded crew back to Bien Hoa- the pilot was

\footnotetext{
121 Ibid.

122 Ibid.

${ }^{123}$ Those in military families were told they would not be stationed within 500 miles of a blood relative due to the possibility of "distractions."

124 Stephens Interview.

125 Ibid.
}

http://ir.uiowa.edu/iowa-historical-review 
Stephens' brother. ${ }^{126}$ After this incident, the $20^{\text {th }}$ Brigade could not keep the information quiet and the rescue story was recounted in the battalion newspaper. Saigon received this information and requested that Stephens stay about a month longer in order to take pictures with her brother for ARC recruitment purposes. Once this endeavor was completed, Stephens was sent to Da Nang.

Before leaving for Da Nang, Stephens was confronted twice more with the scary reality of war-mortar attacks and an intruder. She confessed that these mortar attacks were quite regular, and she was such a sound sleeper that she "would wake up under [the] bed because it [her body] would recognize the incoming versus outgoing [mortars]." One night, a soldier and her unit director dragged Stephens into a bunker because a mortar round had torn through the hootch's roof and Stephens had not woken up. ${ }^{127}$ The intruder incident apparently occurred due to the presence of an African-American Donut Dolly. The hootch was protected by an RPG fence, concertina wire (barbed wire with razors), and an all-night guard outside of the entrance; this allowed the Donut Dollies to feel extremely safe at night. However one night, Stephens was up late working on props for a program and was preparing to go to bed. However, when she was making her way to her room she thought she saw movement in the workroom. Stephens continued to her bedroom and grabbed the only weapon she possessed - a rusty machete that a soldier gave to her. She woke up their director and alerted her to a possible intruder in the workroom. They both walked to the workroom together calling, "Is anyone in here," while turning on the lights. To their surprise, a "big black guy" was in the workroom. ${ }^{128}$ The women were astounded as to how he got into the hootch. The unit director fetched the ARVN guard while Stephens blocked the soldier's path of escape. The soldier's reason for entering the hootch was "I just wanted to see the chocolate Donut Dolly. I heard you had a chocolate Donut Dolly here."

While Da Nang "was a delightful place to work out of," it was not without its share of violence. Stephens recounted two moments in which she feared for her life. The first occurred while programming near the $\mathbf{D M Z}$ during the monsoon season. Programming near the DMZ was strictly against the Red Cross rules, however a General insisted the girls program to his unit. The

\footnotetext{
${ }^{126}$ Ibid.

127 Ibid.

${ }^{128}$ Ibid.
} 
helicopter with the Red Cross girls landed in a crater which was filled with mud due to the rainy season. As Stephens got out of the helicopter and was handed a large canvas bag containing the props for the program, the soldiers and Stephens heard the sound of incoming mortars. She was thrown to the mud and a soldier threw himself over her in order to protect her from any shrapnel. Stephens admitted that she thought, "this is it, this is what we get for not following Saigon orders." ${ }^{129}$ The mortar did not hit near enough to cause any physical damage, but the Red Cross was not pleased with the Donut Dollies working so near the DMZ. The second violent incident occurred again in the hootch while Stephens was asleep. She explained the event as such:

There were only two of us out of the thirteen girls that had previously been assigned to a war zone type of place that had experienced incoming and stuff like that. She was up on the second floor and I was on the first floor, we had roommates. They were big old bedrooms with tall windows and everything. Our only protection was a little old Vietnamese guy that stood out at the end of the driveway. And the constant reassurance was that "oh we were safer than anything." We weren't. I woke up one night with glass from the window my bed was under coming in over me in the bed, and there was three [mortar] rounds that made it into our yard. I had a rusting machete that a guy from the $11^{\text {th }}$ armored cav had given me...I grabbed the rusty machete, the unit director was downstairs also, I told her to get everyone to the bunker. There was a sandbag bunker between the house and the plantation...there was a hallway in between, that was our workroom and storage for working on things at home. The other gal was upstairs, that had experience, she got everyone downstairs. I grabbed the phone, it had a real long extension cord on the phone-it was a field phone, and my machete. This bunker was the saddest bunker I had ever seen in my life! 130

After soldiers rescued the Donut Dollies from their bunker, the unit director insisted that the military supply the SRAO volunteers with an adequate bunker and guard.

Besides the incidents of violence, Stephens had a relatively pleasant experience at Da Nang and subsequently Cam Ranh. Da Nang included the infamous China Beach, which reminded Stephens "of Malibu traffic jams, on a single road." The rec center was large, brand new, and had a music room, a 
library, a "huge rec room with pool tables and foosball and air hockey," and a workroom for the Donut Dollies that was separate from the center. ${ }^{131} \mathrm{Da}$ Nang operated slightly different than Bien Hoa in that the Donut Dollies would rotate between rec center and out field (mobile units) duty. There were also twice as many Donut Dollies, thirteen, than at Bien Hoa. ${ }^{132}$ After Da Nang, Stephens was made a unit director at Cam Ranh Army. Cam Ranh was much smaller and had mobile units close to the Cambodia and Laos borders.

Stephens' relationships with the troops were close to a brother-sister relationship and she was "not interested in getting involved with anyone...You're always sort of teasing the guys or harassing them, that was sort of [her] attitude because of [her] brothers." Stephens, and the other Donut Dollies, were "put on a pedestal" and the soldiers were on their best behavior around them. Thus, "you always did not take them seriously about anything [derogatory] they said about you." 133 Before leaving Bien Hoa for Da Nang, one of the Sergeants made a declaration of undying love. Stephens was convinced he was kidding, but agreed to lunch if he would come to Bien Hoa from Chu du Lai, a forward base. The Sergeant, Mike, hitchhiked to Bien Hoa, which "blew [Stephens] away." Stephens gave him her address so he could write while he adjusted to life back in the States. ${ }^{134}$ Michael called her all the way up to Da Nang on field phones. Eventually he moved back to California and waited for Stephens. ${ }^{135}$ When she eventually returned, she and Mike dated and eventually married. One of the reasons she married Michael was because returning was "sort of strange... [and] I didn't feel like I had to explain anything to him...he knew and I knew."

Returning home brought more of a shock than marrying Michael. While still in Vietnam, a pilot named Dan tried to convince Stephens to return home with him. Stephens refused and Dan was assigned to a base in Ohio when he returned to the States. Due to Dan's close proximity to Stephens' parent's house, he called her parents expressing that he was a friend of both Stephens and her brother John. Her family immediately invited him to dinner because he was a friend from Vietnam. Her parents "fell in love with Dan. He was a pilot, my dad was a pilot. He claimed a twenty-eight year-old virgin. $\mathrm{He}$

\footnotetext{
${ }^{131}$ Ibid.

132 Ibid.

133 Ibid.

134 This was the customary answer for when "they really got down in your face."

135 Stephens Interview.
} 
graduated from a Lutheran Seminary out in California." Her parents were convinced that he was the perfect guy to marry their daughter.

When Stephens came home, they invited Dan over every weekend because they felt that his presence would help her readjust to society. Unbeknownst to her parents, the entire month that Stephens was in town she was making preparations to move to California and live with Michael. The night before Stephens left for California, Dan proposed. Stephens explained that the whole reason she was moving to California was to be with Michael. Stephens went to tell her parents what had occurred, and she came to find out that "the three of them had already arranged the wedding, the reception, the date, everything! All I had to do was say yes, and I said no." Stephens moved to California the next day and six months later when she called her parents to tell them the date of the wedding, her father disinherited her. ${ }^{136}$

Besides marriage and marriage proposals, returning home was difficult because Stephens did not talk about her time in Vietnam and others did not understand. While on a plane to Washington D.C., Stephens met a soldier whom she had programmed to. A lady sitting in the third seat asked Stephens if she had been in Vietnam. When she answered that she had, the lady asked, "what were you doing in that horrible war?"137 Stephens did not know how to respond to this question and remained silent. The soldier leaned over Stephens and said to the lady, "'angels like her and her coworkers is why guys like me come home to bitches like you.' The guy across the aisle clapped his hands and said 'Amen brother."' 138

The only person Stephens discussed Vietnam with was her brother John, and even then the sole purpose for the conversations was for Stephens to listen. Eventually, some of the friends Stephens had made while in Vietnam tracked her down and invited her to a reunion in Fredericksburg. Stephens first called Linda, another Donut Dolly, to ask why Red Cross girls were looking for her. Linda explained, "Well Bobbi, you and I are different, we went on with our lives, some people didn't leave Vietnam." 139 Stephens understood this due to her brother's experiences so she subsequently called her brother and asked to take his daughter, Stephens' eldest niece, to the reunion as well. John explained

\footnotetext{
136 Ibid.

137 Ibid.

138 Ibid.

139 Ibid.
}

http://ir.uiowa.edu/iowa-historical-review 
this sudden change was due to the fact "you've had all this plugged up and corked up in your mind for all these years, and now it's uncorked."

When her experiences from Vietnam came 'uncorked,' Stephens was able to readjust through one of her sorority sisters. She and her husband would invite Mike and Stephens over for barbeques. However Stephens never felt the need to talk about her experiences, and her sorority sister never felt the need to ask, "We never talked about Vietnam. I guess it is sort of strange, but there was never a need to." Eventually the experiences in Vietnam took a toll on Mike's and Stephens' relationship. After witnessing a friend's divorce due to physical abuse, Stephens swore that she would never permit Mike to abuse her. One night after a Christmas party, Mike pushed Stephens from the car onto the highway. After this incident, Stephens and Mike were separated for three years before finalizing a divorce when Mike refused counseling. ${ }^{140}$

Luckily Stephens has not had any lasting severe mental or physical problems due to the war. However, she knows other Donut Dollies who have passed away due to Agent Orange exposure. "Nothing is being provided to the Red Cross. If they're not military, they're not worker's comp. There is at least three of them that I know that suffer from PTSD severely...it interrupts their daily lives...there are others that have died of cancer, that have had miscarriages, that have had deformed babies." 141 Even through all of her experiences, Stephens says, "there is something about shared experiences. I wouldn't have traded that for anything in the world."

\section{Penni Evans}

Penni Evans' background reflects that of other Donut Dollies during the Vietnam War; she loved to travel and work with people, and her father was a Naval Air Reserve pilot during WWII and the Korean War. ${ }^{142}$ Penni Evans, like Kathy Ormond, found out about the SRAO program through her college's career center. The Red Cross was not an immediate career choice for Evans and she seriously looked into the Peace Corps first. However, she discovered there was a language requirement to join the latter and she was "horrible" at foreign languages. ${ }^{143}$ Subsequently, Evans and her friend who worked in the career center decided to look into the Red Cross program. After some basic

\footnotetext{
140 Ibid.

${ }^{141}$ Ibid.

142 Penni Evans Interview with author, July 31, 2013. (Hereafter Evans Interview).

143 Evans Interview.
} 
research about the program, a director from San Francisco came up to Santa Rosa, where Evans was completing her undergrad, and gave her more information about the program. After this interview, Evans took extra courses in order to graduate a semester early because she wanted to join the Red Cross as soon as possible. However after graduating, she found out that there were not any openings until the next spring. ${ }^{144}$

After graduating a semester early, Evans returned to her parent's home in Indianapolis where she interviewed again with the Red Cross; this time she was flown to St. Louis to talk with a director. After a successful interview, Evans was offered a place in the March group and was given the option of Korea or Vietnam. Like most other Donut Dollies that opted for Vietnam, Evans wanted to escape the constant cold and rain of Indianapolis. ${ }^{145}$ Evans accepted the position for the March class sometime in January and, two weeks before she was to leave for Vietnam, was sent to Washington D.C. for the mandated "training". ${ }^{146}$ She remembered being taught military etiquette and how she was supposed to represent the Red Cross both on and off duty. Additionally, Evans was taught how to wear her uniform and to never have a relationship with a soldier. Despite this information, she explains, "What they didn't tell us was what to do about the rumors, the comments, the come-ons." 147

Following the two weeks in Washington D.C., Evans and her class were flown out of San Francisco and into Saigon. The first thing she noticed about Vietnam was the intense heat, even at night. After a few days of processing and additional training in Saigon, Evans was sent to Cam Ranh Air Base from March to August of 1970. She described Cam Ranh as "huge and sprawling" because the base contained a harbor for the Navy Seals and Marines, an Army base with a hospital across the Bay, an Air Force evacuation hospital, and two Recreation Centers for the Dollies; one was close to the hootch and one was situated on the opposite edge of the base. ${ }^{148}$ This second Rec Center was much more vulnerable to attacks because it was separated from the main base area. Evans recalled a Red Alert at this Center during the middle of the day. The SRAO volunteers were required to turn off the lights and music, lock the doors, and not let anyone in or out of the Rec Center. This was a safety precaution, as

\footnotetext{
144 Ibid.

145 Ibid.

${ }^{146}$ Evans used these quotation marks around the word during her interview.

147 Walker, 274.

148 Evans Interview.
} 
sometimes the North Vietnamese soldiers would accompany zapper attacks with mortar rounds. Due to this, the chain of command required that the doors stay locked at all times to prevent zappers from entering the Rec Centers. ${ }^{149}$

The Red Alert was not the only danger that Evans faced while stationed at Cam Ranh Bay. Rocket and mortar attacks were also a staple feature at the base and they were so frequent that she, like many other Donut Dollies, could tell the difference between the incoming and outgoing rocket rounds. ${ }^{150}$ When Cam Ranh was under attack, Evans and the other Donut Dollies were told to stay inside a building until a raid or attack was over because the base was not equipped with bunkers. The only base she was stationed on with bunkers was at $\mathrm{Cu} \mathrm{Chi}$; however, these bunkers were always full of mud and snakes. ${ }^{151}$

The distance to a unit for programming was often extremely variable. Some of Evans' runs were within a few miles of Cam Ranh while others were near the Cambodia and Laos borders. Often the Donut Dollies would plan overnights to the further bases in order to have two solid days of programming with the soldiers. Evans focused her programming on Trivial Pursuit-like games that often involved music or movies popular in the Untied States. At the time, Evans felt that the soldiers were somewhat resistant to the games that they played. One even expressed his opinion so far as to say, 'You're just here to be cock teasers." 152 However, retrospectively Evans believes that the soldiers appreciated the programs due to the overwhelming amount of appreciation she received from veterans years after she returned to the States.

After her station at Cam Ranh, Evans was supposed to be sent to $\mathrm{Cu}$ Chi. However the day before she was to relocate, the director at Cam Ranh was instructed to not let Evans board the helicopter bound for $\mathrm{Cu} \mathrm{Chi}$. The night before Evans was supposed to leave for Cu Chi, a Donut Dolly at that base, Ginny, was murdered by one of the soldiers. ${ }^{153}$ Instead of flying straight to $\mathrm{Cu}$ Chi, Evans was stationed at Long Binh for two months. While at Long Binh, she experienced three unique instances of violence. The first occurred while on a chopper ride to a forward base. The helicopter lost power during the middle

149 Zappers were North Vietnamese soldiers whose mission was to inflict the greatest amount of damage on an enemy. Often these zappers would kill themselves in the process through suicide bombings.

150 Evans Interview.

151 Ibid.

152 Ibid.

153 Ibid. 
of the flight and "came down hard." Another "bird" [helicopter] came in to pick up Evans and another Donut Dolly along with the stranded crewmembers. The crew stayed behind to fix the helicopter, as did the other Donut Dolly due "Uncle Ho's stomach" from the previous landing. ${ }^{154}$ Evans boarded the other helicopter and, when she landed at the forward base, was greeted by a mortar attack. She was forced into a bunker and later found out that the base received fourteen mortar rounds in a matter of a few minutes.

After this attack, Evans along with the helicopter crew that had brought her to the forward base were required to return to Long Binh. Along the way, Evans was able to see the green tracer rounds from the North Vietnamese and the red tracer rounds from the United States and ARVN Army. ${ }^{155}$ During this time period, no one informed Red Cross or military command of Evans' and her partner's whereabouts. This breakdown in communication caused the General on base as well as the Program Director to reprimand Evans, her partner, and the pilot.

The subsequent instance of violence also occurred in a helicopter. While flying to a forward base, the helicopter in front of Evans and the other Donut Dolly began to receive enemy fire. Due to this, the helicopter that Evans was on began to take evasive maneuvers. She explained that this was one of only two times that she got airsick even though she was "prone to airsickness."156 In addition to the violence witnessed while in the helicopter, Evans also experienced "one of the scariest" moments of her life while in a Jeep in Vietnam. While on an unscheduled overnight at Khe Sahn, Evans, the other Donut Dollies, and their escort got lost and ended up over the border in Laos. Due to the loss of radio contact, they were stopped by American troops and questioned as to where they originated. The Donut Dollies and their protection were sent back to basecamp and put on a chopper [helicopter]. However the helicopter was "flying blind" and more than once scraped trees with the blades. Evans admitted that she "didn't think we were going to make it."157

Evans was sent to $\mathrm{Cu} \mathrm{Chi}$ in attempts to reopen the base after Ginny's death. It is Red Cross tradition that when Donut Dollies come to a new base, the "veteran" Donut Dollies will write a letter of welcome for each new girl.

154 Uncle Ho's stomach was a slang term for anxiety.

155 Ibid.

156 Ibid.

157 Ibid.

http://ir.uiowa.edu/iowa-historical-review 
Ironically, Evans' letter of welcome happened to be from Ginny. ${ }^{158}$ At Cu Chi, Evans experienced countless rounds of mortars and rockets and also developed some dissatisfaction with the Red Cross while in $\mathrm{Cu}$ Chi. Every few months the Donut Dollies were required to take R\&R for their mental health. While she was on a required R\&R in Sydney, the Red Cross decided to close the unit at $\mathrm{Cu} \mathrm{Chi}$, this time permanently, because the division was leaving earlier than expected.

Due to the closing of the base, the military insisted that all of the Donut Dollies' things be removed from the hootches while they were on R\&R. Evans had padlocked her door in order to prevent theft; her room was so well protected that the Red Cross had to saw through the chains to enter her room. ${ }^{159}$ They packed all of her belongings but neglected to open one of the drawers in her desk because it was locked. Evans kept her Red Cross identification card, an assortment of handcrafted jewelry that she had specially made, the letter from Ginny, as well as other precious trinkets in the locked drawer. When those packing her belongings discovered the locked drawer, they chose to not attempt to open the drawer. The military then locked the Donut Dollies out of their hootch. When Evans returned and found these items missing from the items collected by the $25^{\text {th }}$ Infantry Division, Evans collaborated with a friend in the military and decided to file a complaint because the actions of the Red Cross were "unprofessional." Instead of attempting to replace the items, the $25^{\text {th }}$ Infantry Division paid her $\$ 200$, about $\$ 1200$ today, to replace the jewelry that was lost. However, the Red Cross did not issue a formal apology, which Evans was hoping to receive. ${ }^{160}$

Besides the theft of her belongings at $\mathrm{Cu} \mathrm{Chi}$, a II Field Force soldier almost sexually assaulted Evans. ${ }^{161}$ This particular soldier would not take her 'no' for an answer and followed her back to her quarters. She states that she would have been sexually assaulted had she not been able to get the padlock off of the gate because "he mauled me as soon as I got to the gate." 162 Evans

158 Ibid.

159 Ibid.

160 Ibid.

161 II Field Force was assigned to the Long Binh area near Cu Chi. Penni Evans did not specify on exactly what base this incident occurred, but it can be inferred that due to the proximity of Long Binh and $\mathrm{Cu}$ Chi that this incident occurred while she was stationed at $\mathrm{Cu}$ Chi.

162 Evans Interview. 
was able to escape this situation but the Red Cross never addressed what occurred that night.

Evans' time at $\mathrm{Cu}$ Chi passed, and she was sent to her last station at Quang Tri from December 1970 until March 1971. Evans experienced a constant bombardment from mortars and rockets because the base was located "along the air strip" near the DMZ. ${ }^{163}$ She explained that one night there was a B52 raid a few miles away and the impacts were so strong that she could "feel the concussions" back at the hootch. While at Quan Tri, Evans also experienced other horrors of war including proliferate drug use by the soldiers as well as fragging of commanding officers-soldiers would purposefully set-off a grenade near a commanding officer in hopes of killing the officer. At this point, Evans said she "had had it" with Vietnam and needed to leave because of the evident deterioration of morale along with a general disrespect for authority, and these instances made her question why the Donut Dollies were actually in Vietnam. ${ }^{164}$ In March 1971, Evans was able to return home.

The return home was extremely difficult for Evans. She originally attempted to acquire a job with the Red Cross overseas in Europe for a few months. However the Red Cross appeared to lead her on a wild goose chase to obtain the position overseas. One director insisted she must file a certain claim once she got back to the United States, and another director stateside insisted it must be done a different way. ${ }^{165}$ This confusion caused Evans to become even more disenchanted with the Red Cross. Besides the misdirection with the Red Cross concerning a job in Europe, the director of the American Red Cross denied that certain events even happened to the Donut Dollies. She "refused to talk about Ginny and PTSD" and insisted "there is nothing wrong with you girls." 166 The director also would not talk about or even acknowledge the proliferation of sexual assault even thought the Donut Dollies knew that a few of them were raped. Evans equates this refusal to acknowledge these instances to the fact that the Red Cross did not realize that Vietnam was a "completely different war" than WWII and Korea "program wise."167

Evans did not begin to unwrap her experiences and feelings until 1983, which she equates to the beginning of her healing. She heard women talking

\footnotetext{
163 Ibid.

164 Ibid.

165 Ibid.

166 Ibid.

167 Ibid.
}

http:/ /ir.uiowa.edu/iowa-historical-review 
about their experiences in Vietnam, which encouraged her to open up about her experiences. Evans underwent multiple therapy sessions of which some therapists insisted that Vietnam was not the issue that plagued her. To cope with her feelings, Evans wrote poetry:

Slowly they come

But even more slowly they fall

Not to stay long

Not this time at all

And yet they are here

So deep within me

The tears that I shed

On the inside they fall

The tears that I've held

For so many years

Will they release

When I stand at the Wall ${ }^{168}$

This poem is representative of her feelings that she held inside about her experiences in Vietnam. Besides poetry, Evans also began to publically speak about her time in Vietnam, an act that helped to assuage the pain. The countless bombings also took their toll on her psychological well-being as Evans began to develop PTSD; today, she is still unnerved by loud noises, avoids large crowds, and continuously has startle reactions. ${ }^{169}$ During her first time visiting the Vietnam Veteran's Memorial, Evans tried to run away, both literally and figuratively, but was held in place by friends. She says this experience was extremely powerful for her because she was depressed and needed to come to terms with her feelings. Evans remembers one friend telling her that it is okay to stand at the Wall because "You are a veteran." 170

168 Penni Evans, "Tears," Behind the Heart, 2002.

${ }^{169}$ Evans Interview.

170 Ibid. 


\section{Conclusion}

My research on the Donut Dollies showcased a variety of factors relating to the violence these women experienced in the war and the psychological effects when they returned home. My major finding is that the Red Cross failed to provide adequate preparation and training to cope with the stress these women would face, both while serving in Vietnam and after returning to the United States. The interviews provide ample evidence in support of this thesis. Kathy Ormond reported that when she returned home she had difficulty adjusting to 'normal' life because she was used to bombs exploding in her vicinity. Jeanne Christie commented on the prevalence of sexual violence and the lack of assistance and concern for the women who became pregnant. The interview with Bobbi Stephens shows the initial reluctance of the women to talk about their traumatic experiences in Vietnam, which included a number of occasions when her base was under attack and she had to take charge to protect the other Donut Dollies. Penni Evans' story vividly conveys the stress of enduring not only the constant barrages of mortars but also a sexual attack and the loss of her personal items, while the Red Cross failed to acknowledge what was happening nor provide assistance. Their actions in Vietnam make the Donut Dollies among the unacknowledged victims and unsung heroes of the Vietnam War. 


\section{Glossary of Terms (Alphabetical)}

ARC: American Red Cross

ARVN: Army of the Republic of Vietnam

DMZ: Demilitarized Zone; line separating North Vietnam from South Vietnam

Dragon Ladies: Derogatory term used for East Asian women meaning strong, domineering, or deceitful; Madam Nhu was branded with this term

Fragging: The act of a lower-ranked soldier purposefully setting-off a grenade near a commanding officer in hopes of killing the officer; often done due to dissatisfaction with the war

II Field Force: Division of the Army; headquarters in Long Binh

Hootch: Living quarters for the Donut Dollies; varied between 'shanty' structures to tents to buildings left over from the French occupation; always protected by some form of physical barrier and usually an ARVN guard

PTSD: Post-Traumatic Stress Disorder

Rec Center or Recreation Center: Center for the Donut Dollies to interact with the soldiers; often guitar playing, card games and other games, Kool-Aid served, etc.

RPG: Rocket Propelled Grenade

SRAO: Supplemental Recreational Aide Overseas; part of the American Red Cross and synonymous with Donut Dolly

TET: Vietnamese New Year

TET Offensive: Countrywide insurgency by the North Vietnamese Army and the Vietcong during the TET holiday

Zapper: North Vietnamese soldier sent on a suicide mission to kill as many American soldiers as possible 


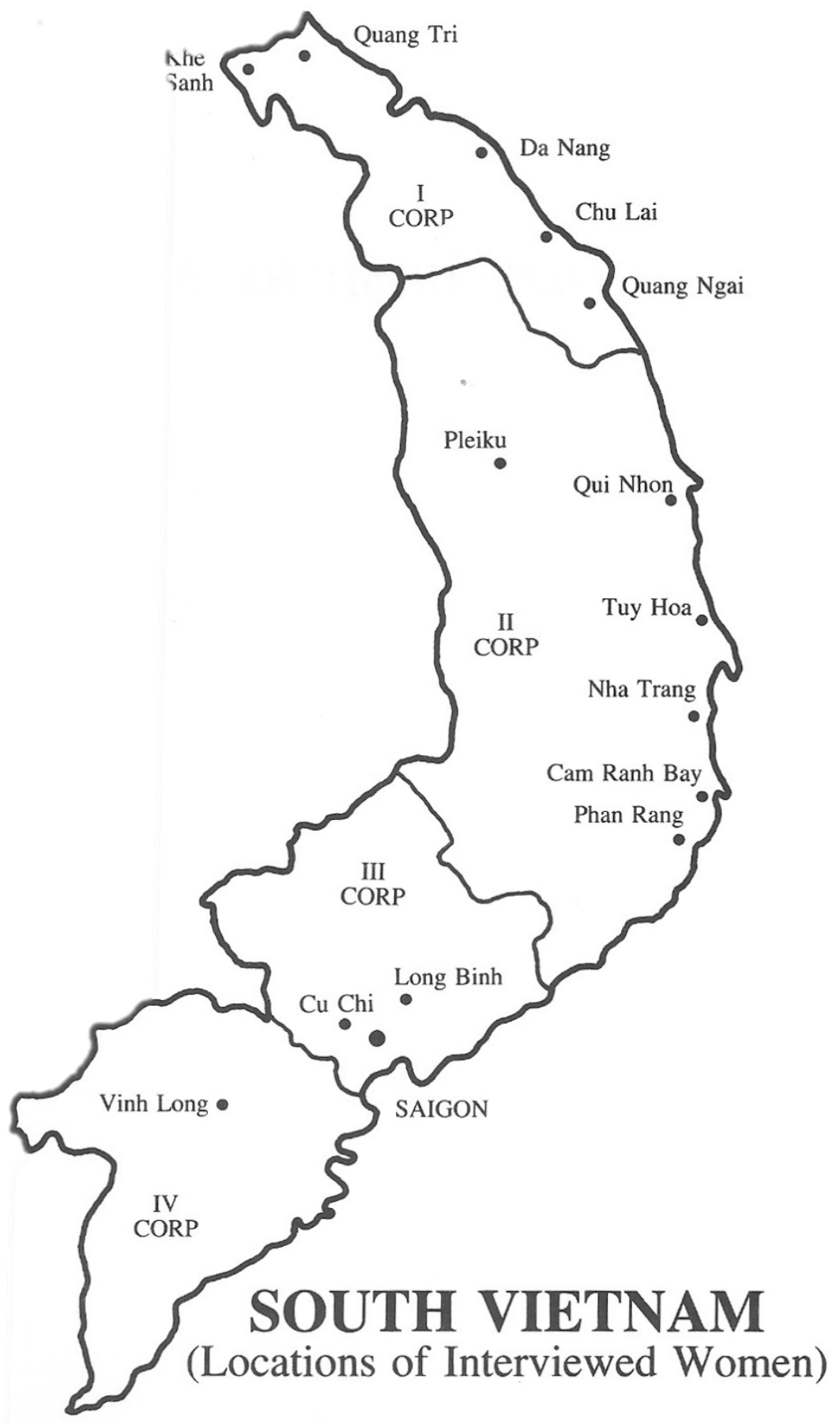

Map of Vietnam With Major Donut Dollies Bases 


\section{Works Cited}

Interview with Barbara Stephens by Ellysa Cassier, July 31, 2013.

Interview with Jeanne Christie by Ellysa Cassier, September 11, 2013.

Interview with Kathy Ormond by Ellysa Cassier, April 21, 2011.

Interview with Penni Evans by Ellysa Cassier, July 31, 2013.

"It Seems Like Only Yesterday...," ARC Information booklet, [n.d], Folder 8, Box 1, Kathy Ormond Papers, Iowa Women's Archives, University of Iowa, Iowa City.

"Norfolk Girl Goes Abroad in Red Cross." The Virginian-Pilot. 2 June 1968, Folder 1, Box 1, Kathy Ormond Papers, Iowa Women's Archives, University of Iowa, Iowa City.

"Time in Vietnam Forever Changed E. Iowa Woman." The Gazette, 24 May 2003, Folder 1, Box 1, Kathy Ormond Papers, Iowa Women's Archives, University of Iowa, Iowa City.

"Vietnam," Government Document for ARC Workers, [n.d], Folder 6, Box 1, Kathy Ormond Papers, Iowa Women's Archives, University of Iowa, Iowa City.

Appy, Christian G. Patriots: The Vietnam War Remembered From All Sides. New York; Penguin Group, 2003.

Bobby to Kathy Ormond, August 12, 1969, Folder 3, Box 1, Kathy Ormond Papers, Iowa Women's Archives, University of Iowa, Iowa City.

Cummings, Sharon Vander Ven. “American Red Cross, SRAO, April 1966-67.” 23 August 1990. Accessed July 31, 2013. www.illyria.com/women/redcross/ rrcummings.html

Cummings, Sharon Vander Ven. "ARC SRAO (Donut Dollies): Frequently Asked Questions. Accessed July 31, 2013. www.crescentwing.com/donutdollies/ $\underline{\mathrm{faq} / \mathrm{html} \# 1}$

Evans, Penni. Behind the Heart. 2002.

Frank to Kathy Ormond, November 11 [1968], Folder 3, Box 1 Kathy Ormond Papers, Iowa Women's Archives, University of Iowa, Iowa City.

Department of the Army Civilian Identification to Kathy Ormond, [n.d], Folder 1, Box 1, Kathy Ormond Papers, Iowa Women's Archives, University of Iowa, Iowa City.

Hurdle, Beth. "Her Job was to Cheer the Fighting Men." Ledger-Star. 15 November 1969, Folder 1, Box 1, Kathy Ormond Papers, Iowa Women’s Archives, University of Iowa, Iowa City.

Kathy Ormond to Jacqueline F. Ormond, August 15, 1968, Folder 5, Box 1, Kathy Ormond Papers, Iowa Women's Archives, University of Iowa, Iowa City.

Kathy Ormond to Jacqueline F. Ormond, February 12, 1968, Folder 4, Box 1, Kathy Ormond Papers, Iowa Women's Archives, University of Iowa, Iowa City. 
Kathy Ormond to Jacqueline F. Ormond, November 17, 1968, Folder 4, Box 1, Kathy Ormond Papers, Iowa Women's Archives, University of Iowa, Iowa City.

Kotcher, Joann Puffer. Donut Dolly: An American Red Cross Girl's War in Vietnam. Denton; University of North Texas Press, 2011.

Kuhlmann, Gary. "Dispatches." Iowa Alumni Magazine (August 2001): [no page numbers], Folder 1, Box 1, Kathy Ormond Papers, Iowa Women's Archives, University of Iowa, Iowa City.

Lawrence, Mark Atwood. The Vietnam War. New York: Oxford University Press, 2008.

Marshall, Kathryn. In the Combat Zone: An Oral History of American Women in Vietnam. Boston: Little, Brown and Company, 1987.

Moore, Waveney Ann. “At reunion in St. Petersburg, 'Donut Dollies' Red Cross workersswap Vietnam War stories.” Tampa Bay Times, 17 July 2010. Accessed July 24, 2013.

Norman A. Durfee, "Special Instructions for Employees Assigned to Duty Overseas," June 1968, Folder 7, Box 1, Kathy Ormond Papers, Iowa Women's Archives, University of Iowa, Iowa City.

Norris, Ann. "Red Cross Girls Train Here for Work in Vietnam, Korea." The Daily Progress. 27 June 1968, Folder 1, Box 1, Kathy Ormond Papers, Iowa Women's Archives, University of Iowa, Iowa City.

Oscar Colbert to Kathy Ormond, [n.d], Folder 13, Box 1, Kathy Ormond Papers, Iowa Women's Archives, University of Iowa, Iowa City.

Passport for Katy Ormond, May 13, 1968, Folder 1, Box 1, Kathy Ormond Papers, Iowa Women's Archives, University of Iowa, Iowa City.

Smith, Sue Davis. "Women of the War: Time to Remember Those Who Served in Vietnam." The Gazette. 7 November 1993, Folder 1, Box 1, Kathy Ormond Papers, Iowa Women's Archives, University of Iowa, Iowa City.

Steinman, Ron. Women in Vietnam. New York: TV Books, 2000.

Strange, Emily. "Angry Black Grunt.” 1998. Accessed July 31, 2013. http://www.emilydd.com/Writings/writings/angry black grunt.htm

Stur, Heather Marie. Beyond Combat: Women and Gender in the Vietnam War Era. New York: Cambridge University Press, 2011.

Walker, Keith. A Piece of My Heart: The Stories of Twenty-Six American Women Who Served in Vietnam. New York: Ballantine Books, 1985.

Walston, Valita A. and Taylor Smith. "A Donut Dolly Reflects on Her Time in Vietnam.” Howard University News Service, 16 November 2008.

William R. Gartrell to Kathy Ormond, [n.d], Folder 3, Box 1, Kathy Ormond Papers, Iowa Women's Archives, University of Iowa, Iowa City. 